\title{
Factors of Economic Growth in the Regions of the North-West Federal District of Russia
}

\author{
Nikolayev M.A, Makhotaeva M.Yu. \\ Pskov State University
}

\begin{abstract}
The purpose of this paper is to identify the factors determining the growth of the regional economy. The research of the influence of the main determinants of economic growth has been executed in the paper: labor force, investments into fixed capital, $R \& D$ expenditure on the index of regions' economy growth. The analysis shows that all these factors made an essential impact on the rates of increase of economy of regions in 2000-2008. Estimating the prospects of the growth of economy of regions in strategic prospect (till 2020) it is necessary to notice that possibilities of the growth at the expense of extensive factors are almost set. In these conditions a steady growth of regional economy is possible only at the expense of an intensification of investment process and strengthening of its innovative component.
\end{abstract}

Keywords: economy of regions, economic growth, investment, innovations, labor force.

\section{INTRODUCTION}

It is known that the territorial factor plays an important and multidimensional role in development of human society and economy. This factor is of particular importance to the Russian Federation. The vast territory of the state, a variety of resources and the business environment on the one hand create certain problems in the development of branches of engineering and social infrastructure, on the other hand they provide manifold opportunities of socioeconomic development, increasing the pace and quality of economic growth. These possibilities are realized, in particular, due to the synergistic effect of interaction of areas with different specialization, integrated into a single value-added chain.

In accordance with this, the territorial factor is given high priority in the scientific literature, as well as in the policy documents of the Russian Federation. In this case a significant asymmetry in the levels of social development and investment activities between the regions of the Russian Federation is considered as limitation of opportunities for economic growth. Thus, the problems of economic growth and regional development are of top priority for all levels of management. These issues are closely related. Without fast economic growth, territorial problems cannot be solved. At the same time, the steady growth of the national economy is possible only in conditions of effective use of competitive advantages of the territories.

Economic growth is a long-term trend in real GDP growth, an integral index indicating the size of economy. In 2008, Russia's GDP was $158 \%$ compared to 2001. In accordance with the main macroeconomic growth indicators, Russia was significantly ahead of most of the developed countries of Europe. So the GDP of Germany in 2008 was only $109 \%$, France $112 \%$, Finland $-122 \%$ and Poland $-136 \%$ compared with 2001. The economy growth rate in Russia was about the same as in Ukraine, Moldova, Latvia, Lithuania and Estonia. Among the former Soviet Union republics, Azerbaijan and Armenia were the leaders in terms of economic growth. In a relatively short period of time Azerbaijan's GDP grew more than three times, and Armenia's - more than twice. Kazakhstan, having close economic ties with our country and a similar economic structure, had higher indicators of economic growth than that of Russia. Sustained high rates of growth of the Chinese economy provided doubling GDP over the period under review [1].

Thus, the growth of the Russian economy, which looked quite good against the developed countries, was significantly behind the indicators of dynamically developing countries with transition economy. This situation is largely due to the underestimation of the role of the territorial factor in social and economic policy of the state. As noted above, a significant asymmetry in the levels of development and investment between the regions currently serves as the main constraint factor to growth of national economy.

The priority of the territorial problems makes actual the search of effective strategies for their solving. In this study, as the first phase of strategy forming, we propose to identify the factors determining the dynamics of the processes of territorial development. At that, the Gross Regional Product (GRP) and the GRP per capita act as the main indicators of level of socio-economic development of the region.

Let us consider the dynamics of the GRP in the North-West Federal District for the period 2001-2008. (See Table 1.).

For the analyzed period, the volume index of GRP of ten regions of the North-West was $173.3 \%$. This growth rate roughly corresponds to the situation in the Russian Federation as a whole. However the growth rates of the economy of regions differed considerably. 
So, the GRP of Leningrad region grew more than twofold, while the economya of the Murmansk region showed a growth of only $12.1 \%$. Thus, within one federal district there is a high differentiation in economic growth. Indicators of a leader (Leningrad region) and an outsider (Murmansk region) differ by nearly an order of magnitude. The high degree of differentiation of the indicators brings into focus the analysis of the factors of regional economies growth.

TABLE 1.

VOLUME INDEX OF GRP IN THE NORTH-WEST FEDERAL DISTRICT (\%)

\begin{tabular}{|l|l|}
\hline Regions & $2008 / 2000$ \\
\hline North-West Federal District & 173,3 \\
\hline Republic of Karelia & 134,5 \\
\hline Republic of Komi & 132,3 \\
\hline Arkhangelsk Region & 185,1 \\
\hline Vologda Region & 133,3 \\
\hline Kaliningrad region & 208,5 \\
\hline Leningrad region & 213,5 \\
\hline Murmansk region & 112,1 \\
\hline Novgorod region & 149,7 \\
\hline Pskov region & 131,8 \\
\hline St. Petersburg & 207,1 \\
\hline
\end{tabular}

Source: Regions of Russia. Socio-economic indicators.

\section{MATERIALS AND METHODS}

To identify the major factors, conditioning economic development of the North-West in the period 2001-2008, it is necessary to refer to the wellknown models of economic growth. Most of the models are based on the fact that an increase in real output is influenced by an increase in the number of basic economic resources and, above all, - labor force and capital. Economic growth, deriving from quantitative expansion of the resource potential of the economy, is called the extensive economic growth. On the other hand, the economic potential of the economy is affected by scientific and technical progress, which leads to improvements in technology and appearance of more advanced types of capital goods. In addition, human capital development contributes to increasing the economic potential of the nation [2]. Economic growth, deriving from of quality improvement of resource potential of the economy, is called the intensive economic growth.

In this article we study the effect of factors such as the number of employed in the economy, investment in fixed assets and R \& D expenditure on the growth of the economy of regions. To assess the degree of influence factors on the growth of the economy, we use the correlation analysis. As a source of information, we use the data of the official statistics.

\section{RESULTS AND DISCUSSION}

At the first stage we consider the impact on economic growth of the extensive factors - the number of the economically active population and investment in physical capital. The dynamics of the economically active population in the North-West for the period 2000-2008 is presented in the Table 2. The period under consideration is characterized by the growth of the economically active population. In the North-West Federal District as a whole, this index increased $4.0 \%$. At the same time, this index has a significant differentiation in the regions. Maximum growth of the economically active population took place in St. Petersburg - by $10.3 \%$. In the Arkhangelsk region the index decreased by $5.7 \%$.

TABLE 2

DYNAMICS OF THE ECONOMICALLY ACTIVE POPULATION

\begin{tabular}{|c|c|c|c|c|}
\hline \multirow[t]{2}{*}{ Region } & \multicolumn{2}{|c|}{$\begin{array}{l}\text { Economically } \\
\text { active population - } \\
\text { total, thousands }\end{array}$} & \multirow{2}{*}{$\begin{array}{l}\text { Change } \\
\text { s, \% } \\
2000- \\
2008\end{array}$} & \multirow{2}{*}{$\begin{array}{l}\text { GRP index, } \\
\% \\
2008 / 2000\end{array}$} \\
\hline & 2000 & 2008 & & \\
\hline $\begin{array}{l}\text { North-West } \\
\text { Federal } \\
\text { District }\end{array}$ & 7394,6 & 7688,0 & 4,0 & 173,3 \\
\hline $\begin{array}{l}\text { Republic of } \\
\text { Karelia }\end{array}$ & 381,0 & 384,0 & 0,8 & 134,5 \\
\hline $\begin{array}{l}\text { Republic of } \\
\text { Komi }\end{array}$ & 547,8 & 570,0 & 4,1 & 132,3 \\
\hline $\begin{array}{l}\text { Arkhangelsk } \\
\text { region }\end{array}$ & 724,2 & 683,0 & $-5,7$ & 185,1 \\
\hline $\begin{array}{l}\text { Vologda } \\
\text { region }\end{array}$ & 667,3 & 659,0 & $-1,2$ & 133,3 \\
\hline $\begin{array}{l}\text { Kaliningrad } \\
\text { region }\end{array}$ & 495,2 & 537,0 & 8,4 & 208,5 \\
\hline $\begin{array}{l}\text { Leningrad } \\
\text { region }\end{array}$ & 855,2 & 918,0 & 7,3 & 213,5 \\
\hline $\begin{array}{l}\text { Murmansk } \\
\text { region }\end{array}$ & 542,3 & 520,0 & $-4,1$ & 112,1 \\
\hline $\begin{array}{l}\text { Novgorod } \\
\text { region }\end{array}$ & 360,3 & 342,0 & $-5,1$ & 149,7 \\
\hline Pskov region & 369,4 & 371,0 & 0,4 & 131,8 \\
\hline St. Petersburg & 2451,8 & 2704,0 & 10,3 & 207,1 \\
\hline
\end{tabular}

Source: Regions of Russia. Socio-economic indicators.

The analysis shows that in all regions with high growth rates of the GRP a significant increase in the economically active population has taken place. The exception is the region with harsh climatic conditions - the Arkhangelsk region. In the regions with low growth rates of the GRP, economically active population decreased or remained about the same. In this group, Republic of Komi, which takes the second place in the district in terms of the GRP per capita, is an exception.

Analysis of the relationship of the growth rates of GRP and changes in the number of economically active population reveals the presence of strong enough correlation between them, where the correlation coefficient is 0.63 . Thus, we can conclude 
that the growth of population involved in the economy was a significant factor in the economic growth of the North-West for the period 2001-2008. This conclusion is entirely consistent with the known models of economic growth.

Next, let us consider the impact of capital on economic growth. Capital is created in the course of investment and, on this basis, we will evaluate its growth in terms of fixed investment. Based on the Table 3 data, we consider the relationship between the level of investment activity in the region and the growth of their economies.

TABLE 3

THE RELATIONSHIP OF INVESTMENT AND ECONOMIC GROWTH

\begin{tabular}{|l|l|l|}
\hline \multirow{2}{*}{ Region } & GRP index, \% & $\begin{array}{l}\text { Index of fixed } \\
\text { investment, \% }\end{array}$ \\
\cline { 2 - 3 } & $2008 / 2000$ \\
\hline Republic of Karelia & 134,5 & 202,0 \\
\hline Republic of Komi & 132,3 & 188,4 \\
\hline Arkhangelsk region & 185,1 & 494,5 \\
\hline Vologda region & 133,3 & 421,0 \\
\hline Kaliningrad region & 208,5 & 478,4 \\
\hline Leningrad region & 213,5 & 284,5 \\
\hline Murmansk region & 112,1 & 276,0 \\
\hline Novgorod region & 149,7 & 299,2 \\
\hline Pskov region & 131,8 & 257,0 \\
\hline St. Petersburg & 207,1 & 400,7 \\
\hline
\end{tabular}

Source: Regions of Russia. Socio-economic indicators.

The analysis shows that the regions differ significantly in terms of investment activity. Thus, in the Republic of Komi investment grew less than twice, while in the Arkhangelsk and Kaliningrad regions - more than 4 times. Quantitative analysis of the relationship between investment and economic growth shows that the correlation coefficient between the GRP index and fixed investment index is 0.58 .

Thus, the level of investment activity is key factor of economic growth and regional development. To assess the prospects for intensification of the investment processes, we should consider the dynamics of processes of gross saving and accumulation. The analysis shows that, in the period 2000-2006, despite the favorable macroeconomic situation - quite stable and high growth rates of the GDP, gross capital formation amounted $20 \%$, and investment in fixed assets - $17 \%$ of the GDP. At the same time, gross saving in all years exceeded $31 \%$ of the GDP. In subsequent years, the situation has improved. In 2000, the correlation of gross capital formation and savings was 0.52 , i.e. only $52 \%$ of the savings were used for accumulation of fixed and working capital; by 2006, the value of the index rose to 0.68 and in 2008 - to 0.81 [3].

The analysis shows that in the 2000s there was a tendency to improve the efficiency of the mechanism of transformation of savings into investments. It was due to the following factors: a disinflation, reduction of risk and interest rates in the economy. In 2000 the inflation rate was $20.2 \%$, and it decreased by 2008 to 13\%. An important guide mark in formation of interest rates in the economy is a refinancing rate. In early 2000 , it was $55 \%$ and decreased by the end of the year to $28 \%$. Then there was a gradual reduction in the rate to $11 \%$ in 2008 .

In recent years the rise phase of the business cycle, situation in investment in Russia has improved significantly. Gross capital formation in 2008 was $25.5 \%$ of the GDP. This rate of accumulation exists in developed countries. This rate of accumulation is sufficient in order to develop an average of 2.5-3\% per year, regularly update well-maintained the basic production assets, maintain and develop the already created a highly developed infrastructure. In Russia, adjusted for high level of wear of fixed assets, a significant lag in housing and infrastructure development, investment rate should be much higher.

In the paper of S. Naryshkin, a problem of gross capital formation is considered from the point of view of national security [4]. By the investment security the author means an ability of the national economic system to generate the investment process, to support sustainable growth and strategic competitiveness of the economy. Investment security policy can be implemented in three areas: ensuring the overall adequacy of investment for sustainable economic development; optimization of branch and territorial structure of the investment; filling the investment process, all investment projects with innovative content. In terms of the overall adequacy of investment, the indicator of the share of savings in the GDP is the most important. For countries with economies in transition, the minimum threshold of gross investment is $25 \%$. Otherwise the normal process of reproduction of basic capital as a foundation for continuous modernization and competitiveness of the national economy is violated. In Russia, a minimum investment threshold of sufficiency economy was reached only in 2008. But in the crisis year of 2009, the share of savings in the GDP has decreased noticeably. The inadequate level of investment activity in the Russian economy is proved by the negative trend of depreciation of fixed assets in the economy. The index grew from $39.3 \%$ in 2000 to $45.3 \%$ in 2008.

Thus, the level of investment activity in the 2000s failed to ensure the sustainable development of the economy in terms of the reproduction of capital. In this case, stability is the most important characteristic of the process of territorial development and it implies the long-term preservation of conditions for reproduction of the region's potential. Thus, we can conclude that the level of investment activity in the 2000s was not able to ensure the reproduction of the economic potential of the territories. In this case, there are significant resources for increasing economic growth by further improving the mechanism of transformation of savings into investments and using 
them to upgrade obsolete production facilities, as well as for infrastructure upgrading.

Next, we consider the impact on economic growth of the technology development, which is the result of innovation. Despite the efforts of the state, indicators of innovation activity of Russian companies remain low. Thus, in 2009 , only $9.4 \%$ of the total number of enterprises of the domestic industry carried out the development and introduction of technological innovations, which is significantly less than in most European countries (Germany (69.7\%), Ireland (56.7\%), Belgium (59 , 6\%), Estonia (55.1\%), Czech Republic (36.6\%)) [1]. Also, the cost structure of technological innovation of Russian enterprises is very different from that of the foreign companies. In Russia, the share of spending on research and development is about a quarter of all the cost. In this case, more than $50 \%$ of the cost of innovation is assigned for the purchase of machinery and equipment. Such a strategy of the apportionment of innovation expenditures is typical for the counties with low scientific potential. In developed countries, the main costs are related to innovative R \& D (70$80 \%$ ).

We can consider the proportion of domestic spending on research and development in the GDP as an integral indicator of innovation activity in the economy. In the 2000s, in Russia this figure was in the range of $1,1-1,25 \%$. This roughly corresponds to the level of European countries, which do not claim to the role of the technological leaders: Spain, Hungary, Portugal, and Estonia. In a number of European countries - Bulgaria, Greece, Latvia - the share of these costs is approximately two times lower. European technology leaders (Germany, Austria, Sweden, Finland, France, and Denmark) have a twice higher index of $\mathrm{R} \& \mathrm{D}$ expenditures than in Russia [1].

Let's consider the level of innovation activity in the regional context. As an indicator we use the share of $\mathrm{R}$ \& D expenditures in the GRP.

The analysis shows that in all regions of the NorthWest Federal District except St. Petersburg, the index value is significantly lower than the average in Russia. In this case, in the regions there is a high level of differentiation in the proportion of expenditures on research and development. The group with a low level of innovation activity includes the Vologda region, the Pskov region and the Arkhangelsk region. In these regions the value of the index does not exceed 0.2. The group with medium level consists of the Republic of Karelia and Republic of Komi, the Kaliningrad region, the Novgorod region, the Leningrad region and the Murmansk region. Their index values do not exceed $0.5 \%$. Only St. Petersburg has a high index of the $\mathrm{R} \& \mathrm{D}$ expenditures in the GRP. Its index is at about the same level as in such countries as Finland and Sweden. In these countries the domestic expenditure on R \& D amounts to 3.73 and $3.75 \%$, respectively, and they are the leaders in Europe for this indicator. Here, however, we should note the negative trend of innovation indicator of St. Petersburg - for the period 2000-2008 it declined from 4.7 to $3.4 \%$ [3].

The analysis shows that the correlation coefficient between the GRP indexes and proportion of $\mathrm{R} \& \mathrm{D}$ costs in the GRP is 0.42 , i.e. the relationship between the indexes is average. Low value of the index apparently is due to the low level of innovative activity in most regions of the North-West Federal District. To assess the prospects of increasing the rate and quality of economic growth due to the intensive factors it is necessary to take into account that Russia is among the world leaders in many indicators characterizing the level of science and technology. In Russia, there is a contradiction between the high scientific and technical potential of the economy and the extremely low level of innovations. Effective use of this potential must provide a significant increase in the rate and quality of growth of regional economies.

\section{CONCLUSIONS}

Thus, we have investigated the effect of employment in the economy, the index of investment in fixed assets and share of the costs of research and development in the gross regional product for the growth rate of GRP. The analysis showed that the most significant factors include the following: an increase in the number of economically active population (correlation coefficient is 0.63 ), the index of investment in fixed capital (the correlation coefficient is 0.58 ). This level of innovation activity showed a slightly lower degree of impact on economic growth (correlation coefficient 0.42 ).

Assessing the prospects for the development of the regional economy in the long term (up to 2020), it should be noted that the growth opportunities due to the factor of increasing the number of the economically active population are almost exhausted. So, according to the average variant of the Rosstat's forecast, the population of working age will decline from 87,524 million people in 2011 to $79,033.2$ million people in 2020 , i.e. $9.7 \%$ [5]. In these conditions, ensuring sustainable growth of the regional economy is only possible due to the intensification of the investment process, which includes increasing public investment in infrastructure, and strengthening its innovation component.

\section{$\mathrm{V}$ REFERENCES}

[1] Russia and the countries of the world. Goskomstat, 2012.

[2] Nikiforov A.A. Macroeconomic: scientific schools, concepts, economic policy: the textbook. - M: Publishing house «Business and Service», 2010. - 624 p.

[3] Regions of Russia. Socio-economic indicators [electronic resource]. The website of the Federal State Statistics Service. Mode of access:

http://www.gks.ru/wps/wcm/connect/rosstat/rosstatsite/main/ publishing/catalog/statisticCollections/doc_1138623506156.

[4] Naryshkin S. Investment safety as the factor of steady economic development// Voprosy Economiki. - 2010. - №5.

[5] The website of Federal Agency of the state statistics http://www.gks.ru/wps/wcm/connect/rosstat/rosstatsite/main/p opulation/demography/\# 